\title{
Utilization of Excess Production of Waste-Fired CHP Plants for District Cooling Supply, an Effective Solution for a Serious Challenge
}

\author{
Mika Fabricius, Daniel Øland Tarp, Thomas Wehl Rasmussen and Ahmad Arabkoohsar * \\ Department of Energy Technology, Aalborg University, 6710 Esbjerg, Denmark; mfabr18@student.aau.dk (M.F.); \\ dtarp17@student.aau.dk (D.Ø.T.); twra18@student.aau.dk (T.W.R.) \\ * Correspondence: ahm@et.aau.dk
}

Received: 17 May 2020; Accepted: 24 June 2020; Published: 29 June 2020

\begin{abstract}
District heating-connected waste incineration plants face a serious operating challenge during the warmer months of the year when the heating load is quite low. The challenge is the difficulty of managing the extra municipal solid waste to be disposed of, exposing great pressure and cost on the plant. Conventionally, the solution is either burning the surplus waste and providing the extra cooling required for the condenser with a summer chiller and paying the tax of the total heat generation of the plant, or paying other industries to burn the waste for their specific applications. Both of these solutions are, however, costly. In this study, to address this challenge the utilization of the extra available resources of waste incineration plants for district cooling supply is proposed. Then, the proposed solution is analyzed from the thermodynamic and economic points of view. The feasibility of the proposal is investigated for a real waste incineration plant in Denmark and its 50 neighboring office/service buildings as the case study. The simulations are done based on real hourly data of the plant and economic parameters. The results show that for the case study for a plant with a thermal capacity of $73 \mathrm{MW}$, a district cooling with a peak load of over $20 \mathrm{MW}$ could be perfectly supplied. The payback period of the proposed solution, including the cost of piping, absorption chiller, etc., can be as short as five years.
\end{abstract}

Keywords: waste incineration; MSW management; district cooling; district heating; techno-economic analysis

\section{Introduction}

The only proven alternative to landfilling for the disposition of post-recycled waste is combustion (so-called waste incineration). Denmark, for example, achieved the highest waste to energy rates (54\%) in the EU-27, while its landfilling was only 4\% in 2010 [1]. In this way, not only are the negative environmental impacts of waste management reduced by half, but free thermal energy is produced for heat and/or power generation [2]. Thus, several different applications could be defined for the generated energy based on local needs and availabilities. For example, Ghouleh and Shao [3] proposed and investigated the use of MSW incineration units for having a sustainable cement industry and producing materials for buildings through the use of generated ash, $\mathrm{CO}_{2}$, etc. coming out of the incineration process. However, the main application of MSW incineration units is in the production chain of energy distribution networks [4].

The literature of studies on MSW incineration heat/power/CHP plants is extensive. Some of the most recent works in this framework are reviewed here. Sadi and Arabkoohsar [5-7] combined a solar-concentrating CHP plant with an MSW incineration unit to remove the need for any thermal battery and to obtain stable power and heat outputs, and studied this in various technical, economic and environmental aspects. Bourtsalas et al. [8] investigated the feasibility of an MSW incineration plant 
for district heating supply in South Korea and concluded that about 1.5 MWh/tonne of MSW net thermal energy could be provided for their case study. Rudra and Tesfagaber [9] analyzed an MSW gasifier plant for cogenerating heat and hydrogen based on a variety of gasification designs/agents. It was shown that significant amounts of heat and hydrogen could be produced $\left(4 \mathrm{~m}^{3}\right.$ water at $100{ }^{\circ} \mathrm{C}$, and approximately $200 \mathrm{~kg}$ hydrogen) for any tonnes of MSW at optimal conditions. Münster and Meibom [10] studied the optimal utilization way of MSW incineration plants for the energy systems (electricity and heat grids) of Northern European countries. Furtenback [11] assessed the role of MSW plants in the district energy systems of Sweden. Nami and Arabkoohsar [12,13] investigated the improvement of power efficiency and decreasing heat output of MSW waste-driven CHP plants by adding a small organic Rankine cycle, and studied this in different technical and economic aspects.

On the other hand, a general understanding of district cooling systems in design, operation and management could be obtained from some extensive review articles published in this area by Gang et al. [14], Werner [15], Inayat and Reza [16], Eveloy and Ayou [17], etc. One of the most important aspects of district cooling systems is examining where and how cooling is provided. Arabkoohsar and Andresen [18] designed a CCP system for district cooling supply in Denmark. This system comprises a large-scale absorption chiller and a trigeneration compressed air-based energy storage system. Nami et al. [19] investigated the trigeneration of heat, power, and cold from a geothermal-driven plant for supplying the distributed energy systems of a case study in Turkey. Wang et al. [20] proposed an innovative configuration of a biomass-driven micro-CCHP plant and analyzed the performance of the system for different seasonal weather conditions. Soltani et al. [21] presented the techno-economic assessment of a CCHP unit with a gas engine for off-design conditions and optimized its operation strategy based on the maximum benefit out of electricity sales. Zare and Takleh [22] proposed a new $\mathrm{CCHP}$ design (via the integration of a Rankine cycle and an ejector transcritical $\mathrm{CO}_{2}$ cycle) driven by geothermal heat. Wu et al. [23] combined a solar thermal system and an organic Rankine cycle to trigenerate cold, heat, and power.

Besides the aforementioned cooling generation systems, the combination of an MSW incineration unit/plant with cold generation systems, such as absorption chillers, for trigeneration has also been addressed in the literature. For example, Hedberg and Danielssen [24] did a feasibility study on a waste-driven chiller for cooling supply in a case study in Thailand. Or, as another example, Nami et al. [25] investigated the performance of waste-driven CCHP systems for supplying heat, cold and electricity grids based on the Turkish energy system's regulations, availabilities and needs. MSW plants are mainly used for the base-load supply of electricity and heat grids; thus, they work at very high load levels close to their nominal capacity throughout the year. For heat-only and CHP waste plants, however, this can be challenging because these are mainly designed for major heat grid supply, while in the summer there is not much heat demand. Thus, the plant cannot operate at a high-load capacity, and this causes several technical and economic challenges, mainly because of the difficult management of the massive amount of waste remaining unburnt at the plant. For addressing this challenge, the current study proposes the utilization of the excess MSW of these plants for providing the required thermal energy for district cooling supply. As mentioned, this is not the first time that a waste-fired cooling system has been proposed and studied. However, any of the previous proposals/studies in this framework come in specific configurations or are designed for particular purposes. The solution given in this article is inspired by the technical summer-operation challenge of district heating-connected MSW CHP plants and requires its specific and precise design. Besides this, the proposed solution is in strong compatibility with the increased cooling need of buildings (even in the Northern European countries due to climate change) and the abundant availability of MSW CHP plants in these energy systems. For investigating the feasibility of the proposed solution and its effectiveness, the proposal is analyzed for a real MSW CHP plant in Denmark and a number of office buildings nearby. The developed cold production system utilizing the excess MSW of the plant, the buildings and the pipeline of the district cooling network are simulated for a number of consecutive 
years (2017-2019) with fluctuating operating conditions. Finally, a detailed techno-economic analysis of the obtained results is presented.

\section{Problem Description and Solution}

\subsection{Problem Description}

An MSW incineration plant should be mainly sized by considering the available amount of MSW for its area of installation. An MSW incineration CHP plant, if allocated for district heating supply, is so designed that the district heating system provides the required cold for the condenser of the power plant (and also for the flue gas condensation unit of the plant, in many cases). These plants need to pay taxes based on their amount of heat generation as they are using MSW, which is not a $100 \%$ clean source. As mentioned before, such plants experience a serious challenge during the low-demand period of district heating systems, i.e., in the warmer months of the year when there is no demand for the produced heat from the district heating side.

For addressing this operation management challenge, there are two potential solutions, both of which impose a great economical cost to the plant. These two solutions and their side effects are:

The power plant needs to have significantly lower operation loads to reduce the required cooling for its condenser part. However, one should note that the amount of produced MSW that the plant commits to burn is approximately the same as in the cold months. Thus, there will be a massive amount of MSW that must be incinerated, but there is no demand for it. In such conditions, the plant needs to pay other industrial enterprises to burn the excess MSW for their specific applications, which is a costly method.

The CHP plant burns all the available MSW and employs a particular summer chiller to provide the extra cooling needed for the condenser. In this case, not only is the excess cooling process costly for the plant, but it also needs to pay heat generation taxes as well, even though its generated heat is not sold and is wasted to the ambient. Thus, this solution is also too costly. It is noteworthy that in this case the flue gas cannot be condensed either and its heat supply potential is simply wasted to the ambient.

Explaining this, one could understand that the challenge is to find a cheaper and wiser method of MSW disposal so that such CHP plants are not exposed to any extra costs.

\subsection{Proposed Solution}

The proposed solution of this work is to utilize the excess heat production capacity of MSW incineration plants for cold production and district cooling supply. This will make for great compatibility between the available MSW and the demand for energy from the incineration plant, which is extremely important for the MSW management system. Apart from that, this solution will not only prevent a huge cost for the disposal of the excess MSW to be burnt, but also make a considerable economic profit via supplying cooling to the end-users. Figure 1 presents a simplified schematic of an MSW incineration CHP plant which is connected to both district heating and cooling systems (via an absorption chiller for the latter). Note that a regular waste incinerator is like a vertical boiler. At the bottom of the incinerator, the MSW is supplied into the chamber and is combusted/incinerated there. Then, the released high-temperature combustion products move towards the exhaust and heat the water pipes in a number of stages along the way to generate superheated steam. The pipings carrying water/steam are positioned at the upper parts of the incineration chamber.

Considering the temperature of available heat at the condenser of the power plant, a single-effect LiBr-water absorption chiller is most appropriate to be connected to the MSW incineration plant for cooling generation. Figure 2 presents the schematic of the absorption chiller, its components and how it utilizes the recovered heat via the condenser of the MSW CHP plant to generate cold for the district cooling network. The figure also presents the values of the temperature and the solution concentration at the most important points of the cycle. A detailed explanation and operation characteristics of single-effect absorption chillers can be found in Florides et al. [26]. 


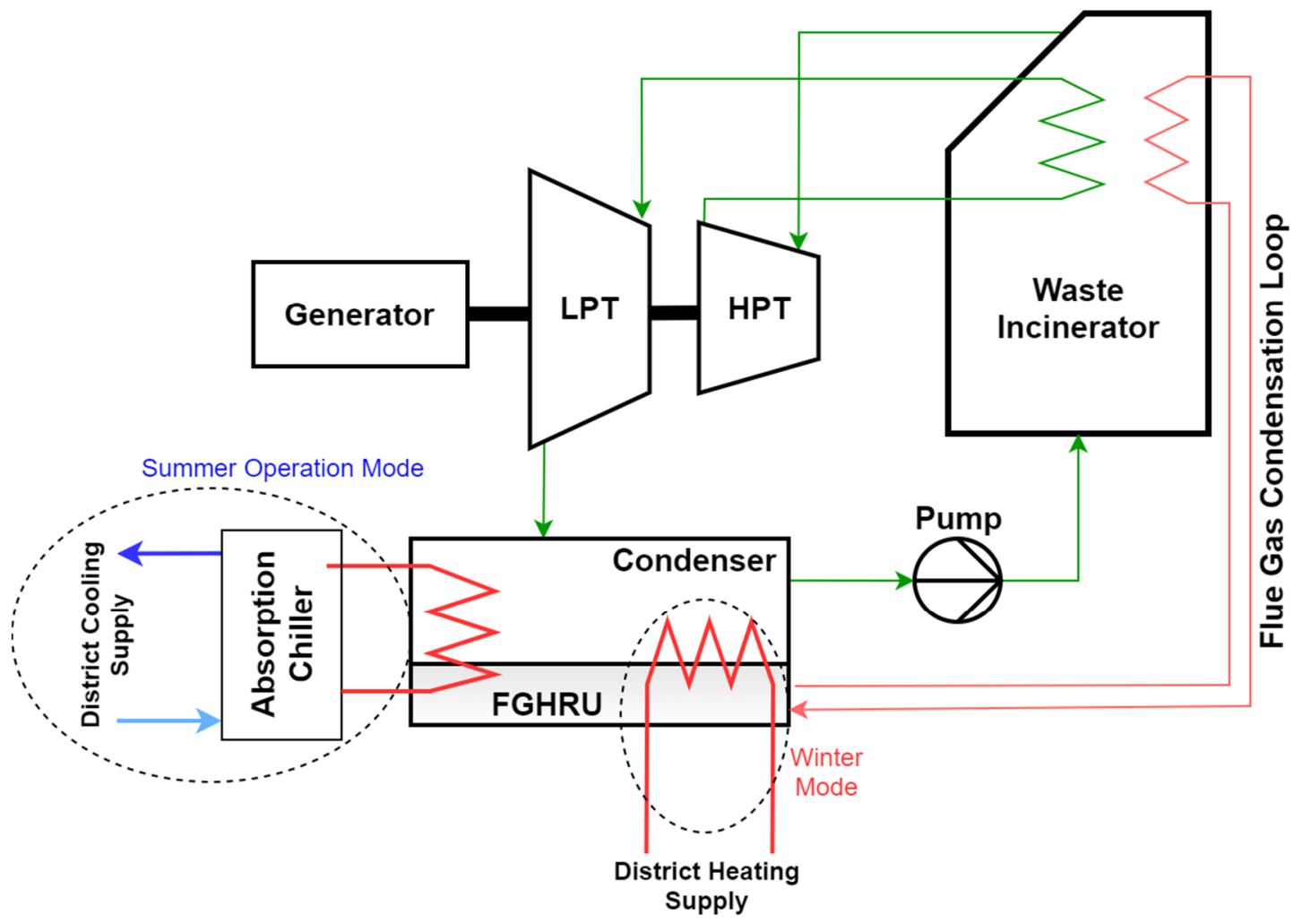

Figure 1. Schematic of the proposed solution; FGHRU: flue gas heat recovery unit; HPT: high-pressure turbine: LPT: low-pressure turbine.

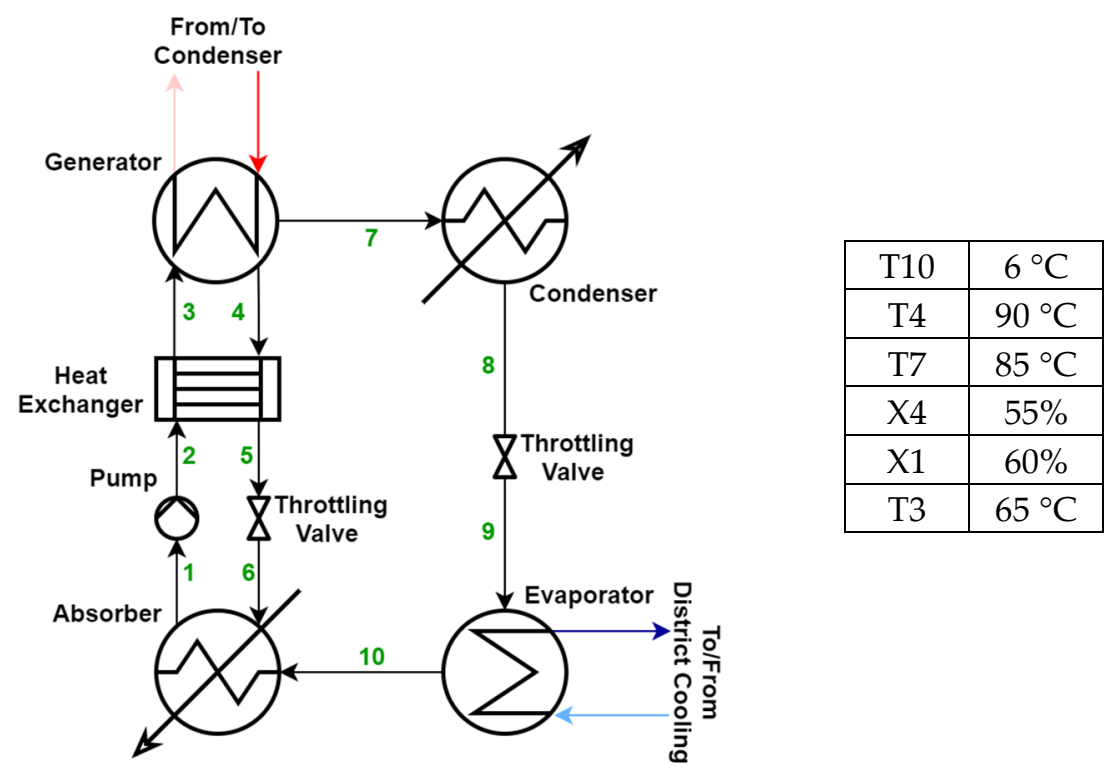

Figure 2. The schematic of the LiBr-water chiller and its operating characteristics; T: temperature, $\mathrm{X}$ : concentration of the solution (the mixture of absorber-refrigerant).

\subsection{Case Study}

The waste incinerator CHP plant of Esbjerg city in Denmark, i.e., the Energnist plant as the case study of this work, has a capacity of 215,000 tons/year and produces heat and electricity to a network of about 25,500 homes [27]. The network of pipes delivering this heat to the homes has been under renovation in the last couple of years (and still is). The purpose of the renovation is to reduce the heat and pressure loss in the system, which in turn reduces the heat production needed to cover the heat 
demand, coupled with the fluctuation of heat demand over the year, resulting in a substantial decrease in heat demand in the summer months. This decrease in heat demand has a downside since the heat is created by burning MSW.

The output from the plant at full load is approximately $60 \mathrm{MW}$ heat from the condenser, $13 \mathrm{MW}$ heat from the flue gas recovery unit and $20 \mathrm{MW}$ electricity. The summer chiller (providing the required condensation cooling by the power cycle) has a maximum capacity of approximately $17 \mathrm{MW}$ dependent on the ambient temperature. At night when the temperature is relatively low, the capacity is close to $20 \mathrm{MW}$, and in the day with temperatures above $30^{\circ} \mathrm{C}$, the capacity drops to around $14 \mathrm{MW}$. The way the Energnist plant handles the decrease in heat demand is that they stop their flue gas condensation, decrease the load on the incinerator and cool the excess heat by an auxiliary summer chiller. The amount of energy not produced from the condensation part is approximately $13 \mathrm{MW}$ during the summer. This is calculated from production data supplied from the Energnist plant, which varies between $10 \mathrm{MW}$ and $17.7 \mathrm{MW}$, with an average of $13 \mathrm{MW}$ and most values between $12 \mathrm{MW}$ and $14 \mathrm{MW}$. This has two drawbacks: they cannot keep up with burning the MSW that is being produced in their area, and they, therefore, have to pay for the transport and the incineration of excess MSW in another incinerator with enough capacity, which is $300 \mathrm{~km}$ away from the plant's site. This increases the price of heat for district heating supply, as they have to pay approximately 1000 DKK ( 135 EUR) per tonne of MSW plus the transportation cost. Figure 3 presents information about the rate of MSW burnt in the case study plant and the rate of potential heat supply wasted due to the lack of heat demand in the district heating system in this plant during an entire year [27].

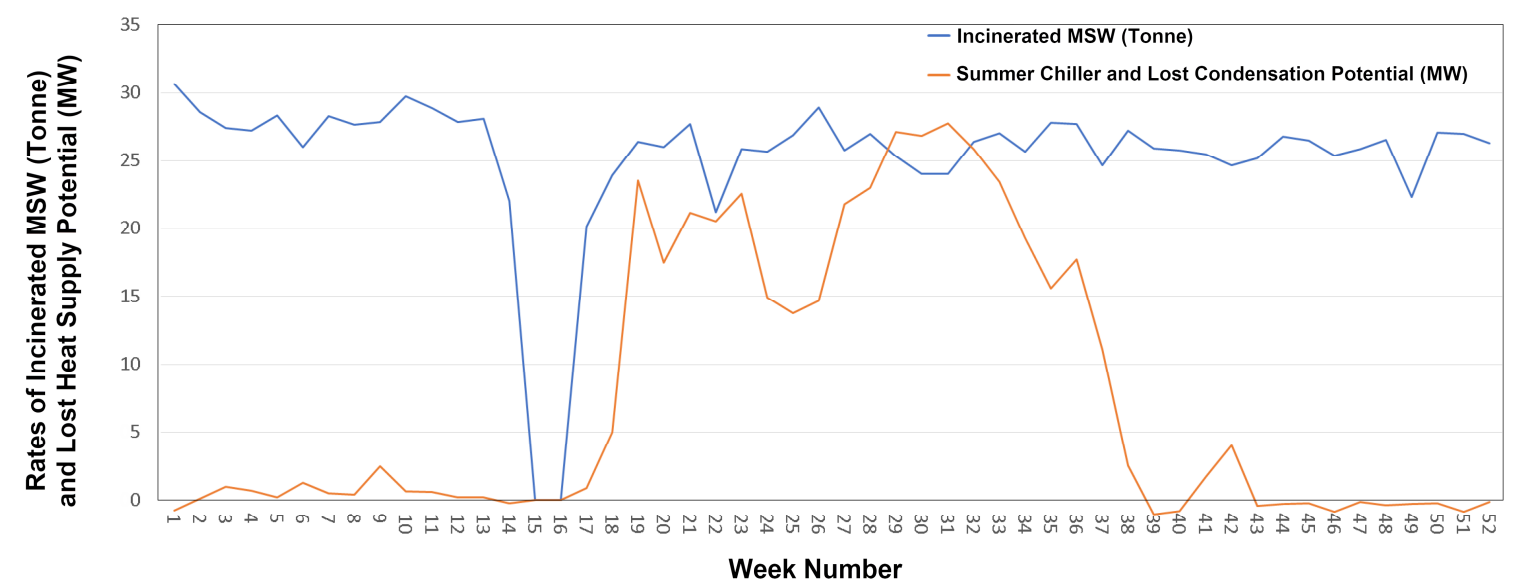

Figure 3. Rate of wasted MSW (in tonnes/week) and wasted heat supply potential of the plant (in MW) for a year.

Having this information, one could size the required absorption chiller for the utilization of all the excess MSW of the CHP plant. A maximum of about $30 \mathrm{MW}$ excess heat shows the potential for a reasonably extensive district cooling network. However, in this work, the aim is to develop a smaller district cooling network by taking advantage of a portion of the available surplus heat to show the feasibility of the proposal. Once the viability of the proposed solution is approved, a more extensive district cooling system may be constructed in practice by utilizing all the available heat of the power plant. The case study district cooling network is assumed to be a neighboring area with several office buildings. The office buildings are located at the Esbjerg harbor, where the district heating accumulation tank is also placed. The setup for this case study is represented in Figure 4. This case study considers 50 office buildings to be cooled down by the district cooling system, each with 400 people in them where 350 of them have a personal computer, and there is one server room per office building [28].

This district cooling system consists of two streets in opposite directions, and each street contains 25 office buildings. It's assumed that the distance of the transmission line is $657 \mathrm{~m}$ and that there is an 
$80 \mathrm{~m}$ distribution line to the first building. Between the distribution lines to each office building there is $110 \mathrm{~m}$ distance, and each office building has $1800 \mathrm{~m}^{2}$ area per floor and has seven floors in total with a wall height of $3.5 \mathrm{~m}$ each. The buildings are based on a rectangular field of $60 \mathrm{~m} \times 30 \mathrm{~m}$. Figure 5 shows the simplified schematic of the district cooling network.

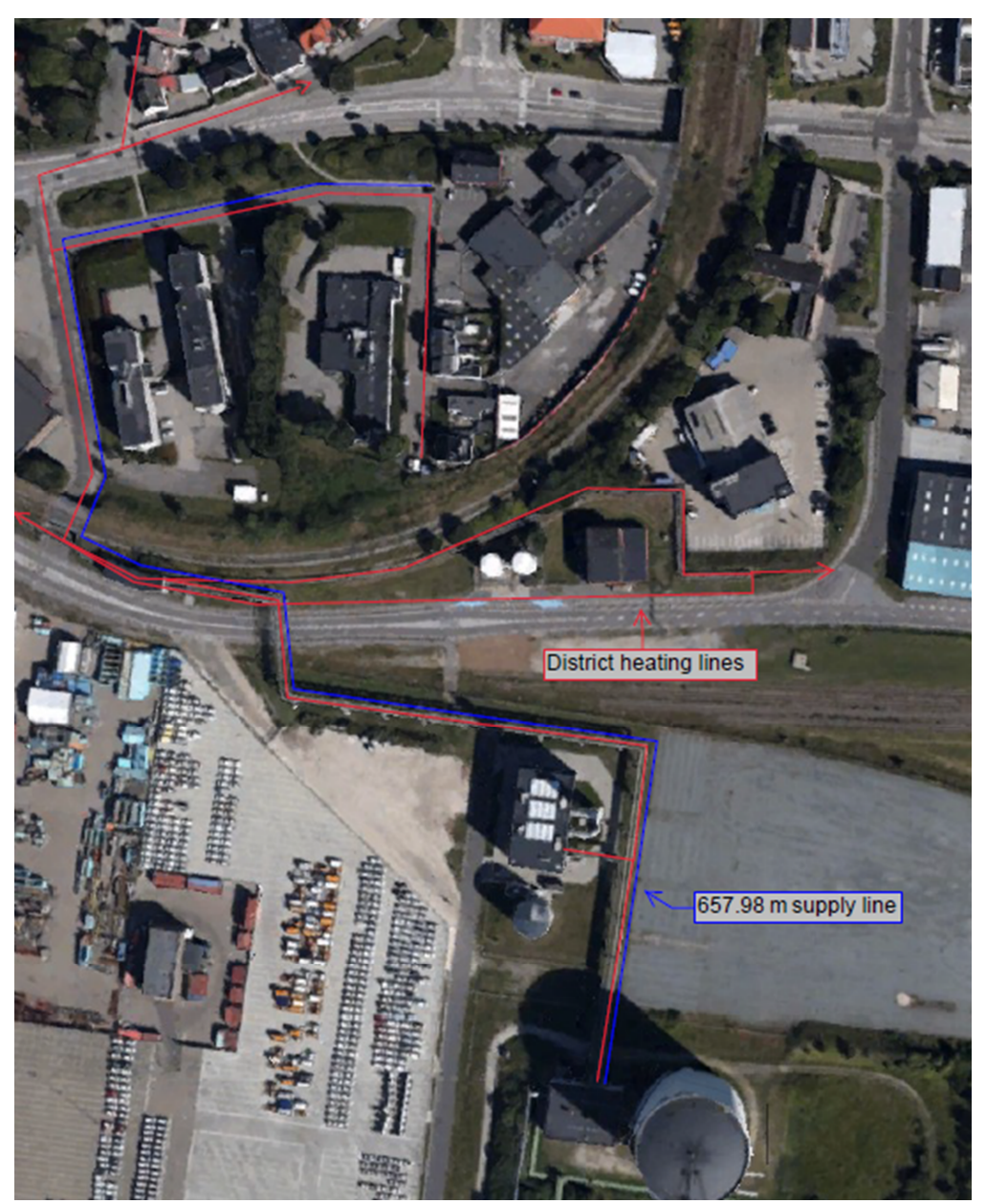

Figure 4. The map of where the district cooling system is to be developed.

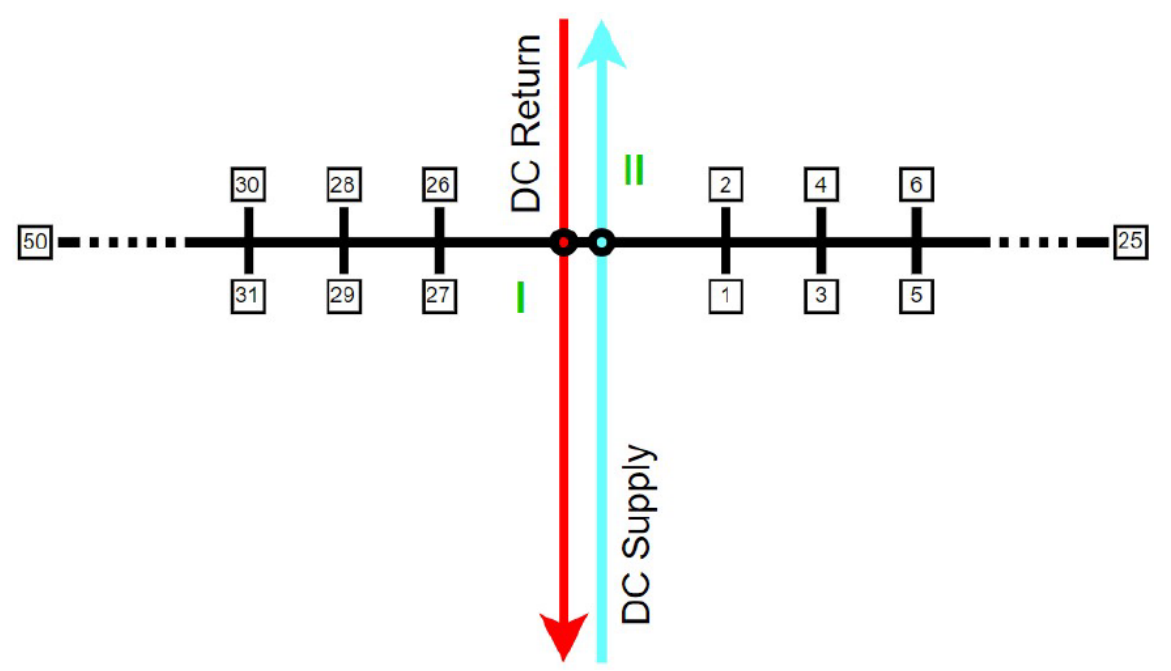

Figure 5. The setup for the district cooling supply and return lines for the office buildings. 
The calculation of the cooling demand for the office buildings in this case study is based on the temperature gain/loss factors of the buildings' materials and interior. The values for the temperature gain/loss through the building materials for Denmark are stated in the Danish building regulations [29]. The heat loss/gain factors, according to the Danish building regulations [29], are $0.3 \mathrm{~W} / \mathrm{m}^{2} \mathrm{~K}$ for the walls (which consists of $30 \%$ of the office buildings total shell surface), $0.2 \mathrm{~W} / \mathrm{m}^{2} \mathrm{~K}$ for the roof and floor ( $20 \%$ of the shell surface each), and $1.8 \mathrm{~W} / \mathrm{m}^{2} \mathrm{~K}$ for windows ( $30 \%$ of the shell surface). The percentage of the shell surface is based on regular office buildings, which tend to have more windows than residential houses. This comes to an overall heat loss/gain factor of $0.71 \mathrm{~W} / \mathrm{m}^{2} \mathrm{~K}$. The Danish indoor comfort temperature is $22^{\circ} \mathrm{C}$, according to the Danish Working Environment Service [30]. The regulations for the ventilation are stated in reference [29], which states a minimum of $5.0 \mathrm{~L} / \mathrm{s}$ per adult and $0.35 \mathrm{~L} / \mathrm{s}$ per square meter of the floor area for office buildings.

Having this information and calculating the rate of the demand of the buildings based on the local ambient temperature and solar energy availability in the case study throughout a year, one could indicate the chiller operation details for the district cooling network, including the rate of heating/cooling dissipated/generated from/by the chiller, operating temperature levels, etc. Figure 6 presents the ambient temperature of Esbjerg and the available solar irradiation over an entire year, and Figure 7 presents a black box of the chiller operation temperature/energy ranges.

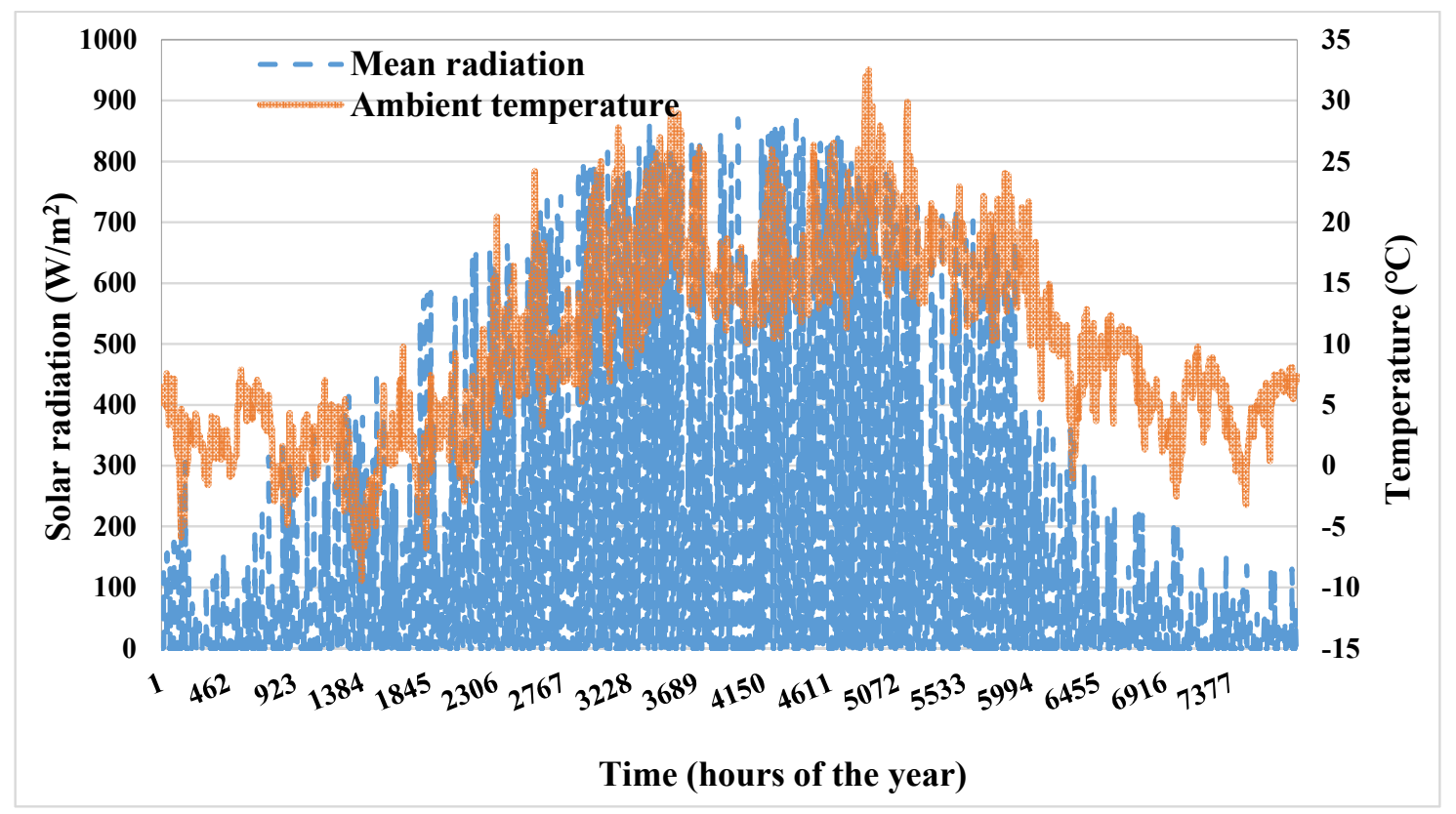

Figure 6. Hourly averaged ambient temperature and solar irradiation in Esbjerg throughout 2018.

According to Figure 7, the supply and return temperatures of district cooling are $8{ }^{\circ} \mathrm{C}$ and $15^{\circ} \mathrm{C}$, respectively, and the supply and return lines of the heat source of the chiller are set at $95^{\circ} \mathrm{C}$ and 72 ${ }^{\circ} \mathrm{C}$ [31]. The method of sizing of the chiller for a nominal cold production rate of $6.7 \mathrm{MW}$ will be discussed in the results section. 


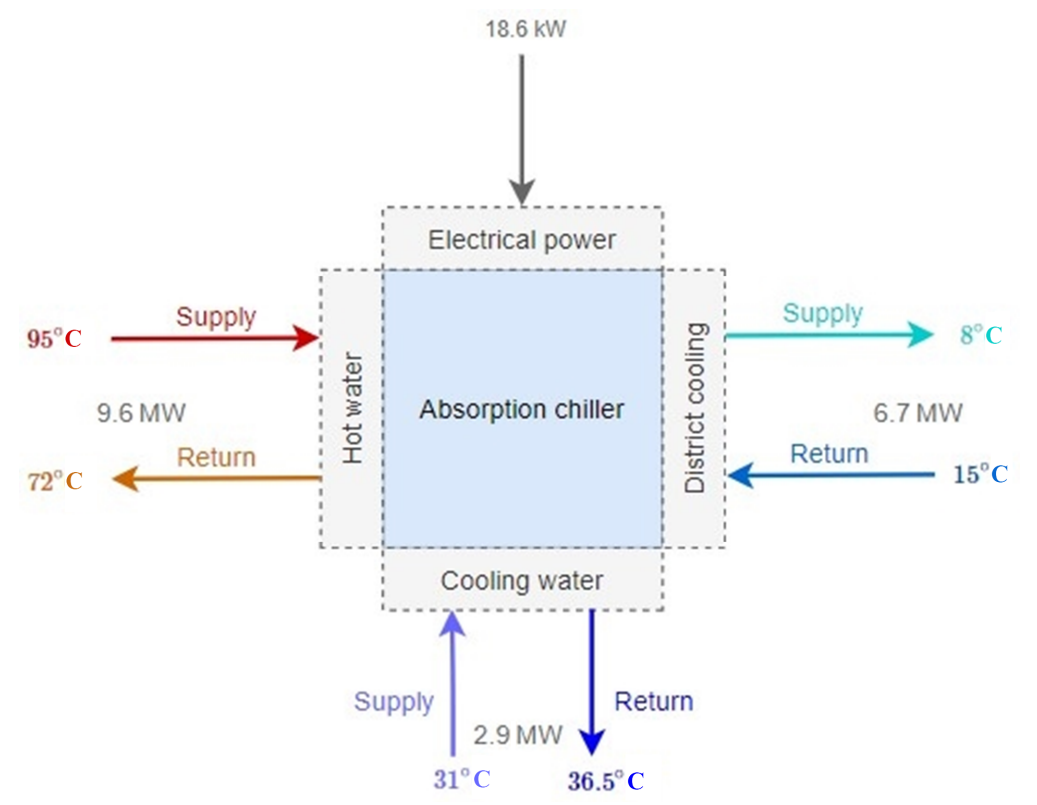

Figure 7. An illustration of the energy flows into/from the absorption chiller when connected to the MSW incineration plant for district cooling supply.

\section{Techno-Economic Model}

\subsection{Thermodynamic Model}

To model the district cooling, cooling demand, pipe sizing, heat loss and pressure loss rates have to be taken into consideration.

The cooling demand of buildings is dependent on various parameters, such as the building materials and the gain/loss factors that were presented earlier, together with the indoor and outdoor ambient temperatures, the temperature gain through the people in the office buildings and their computers, the dimensions of the office buildings, etc. The demand for cooling, according to Reference [32], can be calculated as:

$$
\dot{Q}_{c}=\overbrace{\rho_{a} \dot{V}_{\text {ven }} c_{p, a}\left(T_{\text {in }}-T_{\text {out }}\right)+U A_{l, b}\left(T_{\text {out }}-T_{\text {in }}\right)}^{\dot{Q}_{\text {lost }}}+\overbrace{\sum_{n=1}^{M}\left(A_{n} I_{T}(\tau \alpha)_{\text {avg }}\right)+Q_{\text {interior }}}^{\dot{Q}_{\text {gained }}} \overbrace{\rho_{b m} V_{b m} c_{p, b m} \frac{d T_{b m}}{d t}}^{\dot{Q}_{\text {stored }}}
$$

in which $\mathrm{r}$ is the density, $V$ is the volume, and $T$ is the temperature. The subscriptions $a$, in, out, $b$ and $b m$ refer to the air within the building, the indoor condition, the outdoor/ambient condition, the building and the building material, respectively. In addition, all the different independent variables each represent an energy flow either flowing into the building or flowing out from the building. $\dot{Q}_{\text {lost }}$ is the sum of two total rates of cooling losses of the building due to the ventilation and losses through the building material because of the differences in ambient and indoor temperatures. Here, $\dot{V}_{\text {ven }}$ is the volume flow rate of air exchanged for ventilation, $c_{p, a}$ is the specific heat capacity for air and $U$ is the total heat loss/gain coefficient through the walls, windows, etc., and $A_{l, b}$ is the total shell surface area. $\dot{Q}_{\text {stored }}$ represents the stored rate of energy in the building stuck (this is zero when the steady-state conditions are met). $\dot{Q}_{\text {gained }}$ represents the heat gain due to solar irradiation, where $A_{n}$ is the area of each window, $I_{T}$ is the solar irradiation through the windows and $(\tau \alpha)_{a v g}$ is the average transmission absorption coefficient of the windows and the interior elements of the office building when exposed to solar irradiation. 
The internal gain because of the office workers' metabolism, the heat from computers, etc. can be found using:

$$
\dot{Q}_{\text {interior }}=\overbrace{\sum_{j=1}^{N} \dot{Q}_{e l, j}}^{\text {Electrical Devices }}+\overbrace{M\left(M R \times A_{\text {avg }}\right)}^{\text {Metabolism Heat }}
$$

In this equation, $\dot{Q}_{e l}$ is the rate of heat produced by each of the electrical devices in the buildings ( $N$ devices in total). Here, the majority of electrical heat comes from computers; 350 computers in total were considered for the buildings, each of which generates $200 \mathrm{~W}$ as a normal desktop computer. $m$ is the number of people in one office building, which is 400 for the case study. MR is the metabolic rate, and according to the ANSI ASHRAE standard for 2017 [33], it is about $71.66 \mathrm{~W} / \mathrm{m}^{2}$. $A_{\text {avg }}$ is the average surface area of a male, which according to Reference [34] is estimated to be about $1.7139 \mathrm{~m}^{2}$.

Regarding the pipeline, some assumptions are made for calculating the pressure and thermal loss rates. It is assumed that minor losses (e.g., reductions, valves, etc.) account for $20 \%$ of major losses made by friction in the pipe [35]. According to DIN Forsyning [36], the maximum pressure in the district energy systems of this area should be $10 \mathrm{bar}$, and there must be an available differential pressure between 0.2 and 4 bar at the consumer. For calculating the heat gain/loss to the surroundings, when underground it is assumed that the surrounding soil is at ambient temperature since its close to the surface. Heat losses can be calculated by:

$$
\dot{Q}_{\text {loss }}=\sum_{j=1}^{J}\left[\left(\frac{1}{h \pi d_{\text {in }} x_{j}}+\frac{\ln \left(\frac{r_{\text {out }}}{r_{\text {in }}}\right)_{j}}{2 k_{p} \pi x_{j}}+\frac{\ln \left(\frac{r_{\text {ins out }}}{r_{\text {ins.in }}}\right)_{j}}{2 k_{\text {ins }} \pi x_{j}}\right)^{-1}\left(T_{\text {in }}-T_{s}\right)_{j}\right] ;
$$

where: $h=\frac{0.023 R e_{D}^{0.8} P r^{0.4} k}{d_{i n}}$, in which $j$ refers to different pipe sections (with $J$ numbers in total). In addition, $r$ is radius and the subscripts in, out, and ins represent the terms internal, external and insulation, respectively. $k$ is the thermal conductivity factor, $h$ is the convection factor, and the subscripts $p$ is for the pipe material [37]:

Pressure losses are calculated by [35]:

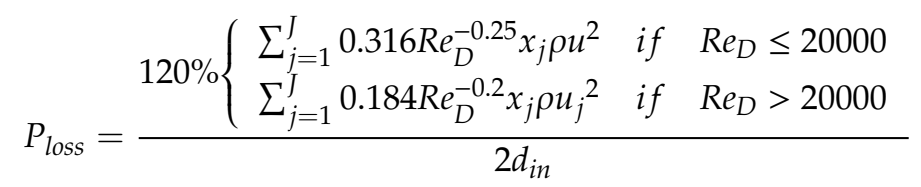

Besides, in the supply line, an added pressure loss rate due to the height difference from the inlet of the pipe to where the pipe is divided into the two branches is considered. The approximated height difference is $12.5 \mathrm{~m}$ according to the Board of Data Supply and Efficiency Improvement [38].

Having these, one can then calculate the required booster pump energy consumption for pressure loss compensation through the network of pipes [39]:

$$
\dot{W}_{\text {pump }}=\frac{\sum_{j=1}^{J} \dot{m}_{j} v P_{l o s s, j}}{\eta_{\text {pump }}}
$$

$\eta_{\text {pump }}$ is the pump energy conversion efficiency here. The internal diameter of the pipes in each section is calculated based on the maximum allowed velocity of the pipe $(2 \mathrm{~m} / \mathrm{s}$ [40]) and the maximum mass flow rate of the medium through the pipe in the given section over the year. Thus:

$$
d_{j}=\sqrt{\frac{4 \max \left(\dot{m}_{c}\right)_{j}}{\rho u_{\max } \pi}}
$$


As mentioned, a detailed model of absorption chillers could be found in [26]. Here, the general thermodynamic correlations of the main components of the chiller are presented. According to the mass balance on the evaporator, $\dot{m}_{9}=\dot{m}_{10}$, the energy balance is:

$$
\dot{Q}_{e}=\dot{m}_{10} h_{10}-\dot{m}_{9} h_{9}=\dot{m}_{d c w} c_{w}\left(T_{d c s}-T_{d c r}\right)
$$

where $\dot{m}_{d c w}$ is the flow rate of district cooling water to be cooled through the chiller, $c_{w}$ is the thermal capacity of the pressurized water, $T_{d c s}$ is the supply temperature of district cooling water $\left(8^{\circ} \mathrm{C}\right)$ and $T_{d c r}$ is its return temperature $\left(15^{\circ} \mathrm{C}\right)$.

Based on the mass balance on the absorber, $\dot{m}_{1}=\dot{m}_{10}+\dot{m}_{6}$ and $\dot{m}_{1} x_{1}=\dot{m}_{6} x_{6}$, the energy balance could be written as:

$$
\dot{Q}_{a}=\dot{m}_{10} h_{10}+\dot{m}_{6} h_{6}-\dot{m}_{1} h_{1}
$$

Having $\dot{m}_{8}=\dot{m}_{7}$, the energy balance of the condenser could be written as:

$$
\dot{Q}_{c}=\dot{m}_{7}\left(h_{7}-h_{8}\right)
$$

Finally, the energy balance on the generator of the chiller is as (where, $\dot{m}_{3}=\dot{m}_{4}+\dot{m}_{7}$ ):

$$
\dot{Q}_{g}=\dot{m}_{4} h_{4}+\dot{m}_{7} h_{7}-\dot{m}_{3} h_{3}
$$

Naturally, $\dot{Q}_{g}$ is the amount of heat recovered from the CHP plant, supplied by excess MSW. To obtain the value of this parameter, the mode of the MSW CHP plant should be written. The following correlations present the energy models of the main components of the plant. For the incinerator, which is the boiler of the steam cycle, one has:

$$
\dot{Q}_{i n c}=\eta_{\text {inc }} \dot{m}_{m s w} L H V_{m s w}=\dot{m}_{s}\left[\left(h_{\text {out }}-h_{\text {in }}\right)_{\text {main }}+\left(h_{\text {out }}-h_{\text {in }}\right)_{\text {regen }}\right]
$$

In this equation, $\eta_{i n c}$ is the incinerator energy efficiency (0.85), $L H V$ is the lower heating value of the MSW and $\dot{m}_{S}$ and $\dot{m}_{S}$ are the mass flow rates of required MSW and steam (or pressurized water as the working fluid of the Rankine cycle). The subscripts "main" and "regen" refer to the main and regeneration lines of steam passing through the incinerator.

For the steam turbine, one has [41]:

$$
\dot{W}_{\text {tur }}=\dot{m}_{s}\left[\left(h_{\text {in }}-h_{\text {out }}\right)_{h p t}+\left(h_{\text {in }}-h_{\text {out }}\right)_{l p t}\right]
$$

where "hpt" and "lpt" are the high-pressure and low-pressure turbines of the cycle.

For the condenser, one has:

$$
\left.\dot{Q}_{\text {cond }}=\dot{m}_{s} h_{f g}\right]_{T_{\text {sat }}}
$$

in which $h_{f g}$ is the latent heat of steam from vapor to liquid at the phase change temperature in the condenser $\left(T_{\text {sat }}\right)$.

The heat recoverable from the flue gas, in ordinary operation conditions (not during the summertime), is calculated by:

$$
\left.\dot{Q}_{f g}=\dot{m}_{f g}\left(h_{f g, 1}-h_{f g, 2}\right)+\dot{m}_{w} h_{f g}\right]_{T_{s a t, f g}}
$$

The first term on the right side of the equation presents the rate of heat released from the flue gas, decreasing its temperature from what it is at the incinerator outlet to the due point of its water content, and $\left.h_{f g}\right]_{T_{\text {sat }, f g}}$ is the amount of energy released due to flue gas condensation. 


\subsection{Economic Model}

The economic assessment method of this study is based on the net present value (NPV) approach. This method is one of the most reliable economic analysis approaches for financial investments in projects, including the energy industry. The NPV method considers the critical parameters on the economy of the project, including the local interest rate, the initial investment, the annual running expenses, the annual benefits of the project, the useful lifetime of the project, etc. The NPV of the proposed cold supply project of this work is calculated by [42]:

$$
N P V=\sum_{t=0}^{25} \frac{(\text { Total Annual Benefits }- \text { Total Annual Costs })_{t}}{(1+\text { Interest Rate })^{t}}
$$

In this equation, $t$ is the number of operating years of the system and starts from 0 because the year of investment for establishing the system and its fundamentals is all costs, and there is no benefit out of the system. From the first year $(t=1)$, the system starts generating profits, and of course there are still operating and maintenance costs, too. This will continue for 25 years $(t=25)$ as the useful lifetime of the system, though the system components can still be working and generating a profit for a longer period. Table 1 gives information about the economic parameters considered for calculating the NPV of the project.

Table 1. Input parameters for the economic assessment algorithm.

\begin{tabular}{cc}
\hline Parameter & Value and Unit \\
\hline Chiller Capital Exenditure (CAPEX) & $430 \mathrm{USD} / \mathrm{TR}[43]$ \\
\hline Storage Tank CAPEX & $290 \mathrm{USD} / \mathrm{m}^{3}[44]$ \\
\hline Average Pipeline CAPEX (including installation costs and possible discounts) & $160 \mathrm{USD} / \mathrm{m}^{*}[45]$ \\
\hline Interest rate & $10 \%$ \\
\hline Annual maintenance costs & $3 \%$ of the total CAPEX \\
\hline Cold production price & $30.5 \mathrm{USD} / \mathrm{MWh}$ * [18] \\
\hline Electricity production price & $32.7 \mathrm{USD} / \mathrm{MWh}$ * [18] \\
\hline
\end{tabular}

Note that in this project:

- The waste heat of the plant is utilized for running the chiller; thus, the costs associated with the heat used for driving the cold system is zero. Instead, the taxes to be paid for extra heat generation are taken into account based on different taxation scenarios. The lowest heat generation tax is said to be $75 \mathrm{DKK} / \mathrm{MWh}$, but it can also be higher [27]. These all have been taken into account in the economic calculations.

- Electricity consumption in the system (for running the pumps, etc.) is supplied by the plant itself; therefore, the electricity production price is considered for calculating the running expenses of the system.

- The cooling supplied to the office buildings is the main source of profit for the system.

- Preventing the extra costs for waste disposal and its transportation due to the added cold supply unit are considered as the secondary source of profit for the system.

\section{Results and Discussions}

In this section, the results of the simulations on the proposed system in the case study are presented and discussed.

As mentioned, one of the critical parameters for calculating the cooling demand of the buildings is the effect of solar irradiation. Figure 8 shows the impact of solar irradiation level, apart from the 
ambient temperature effects, on the increased cooling demand of the buildings in an hourly averaged format. As seen, July has the highest weight factor of solar irradiation effect on the increased cooling demand of the buildings with a mean peak value of $2{ }^{\circ} \mathrm{C}$ at noon. The lowest values are of course related to winter months, which are out of consideration due to lack of demand for cooling in these months.

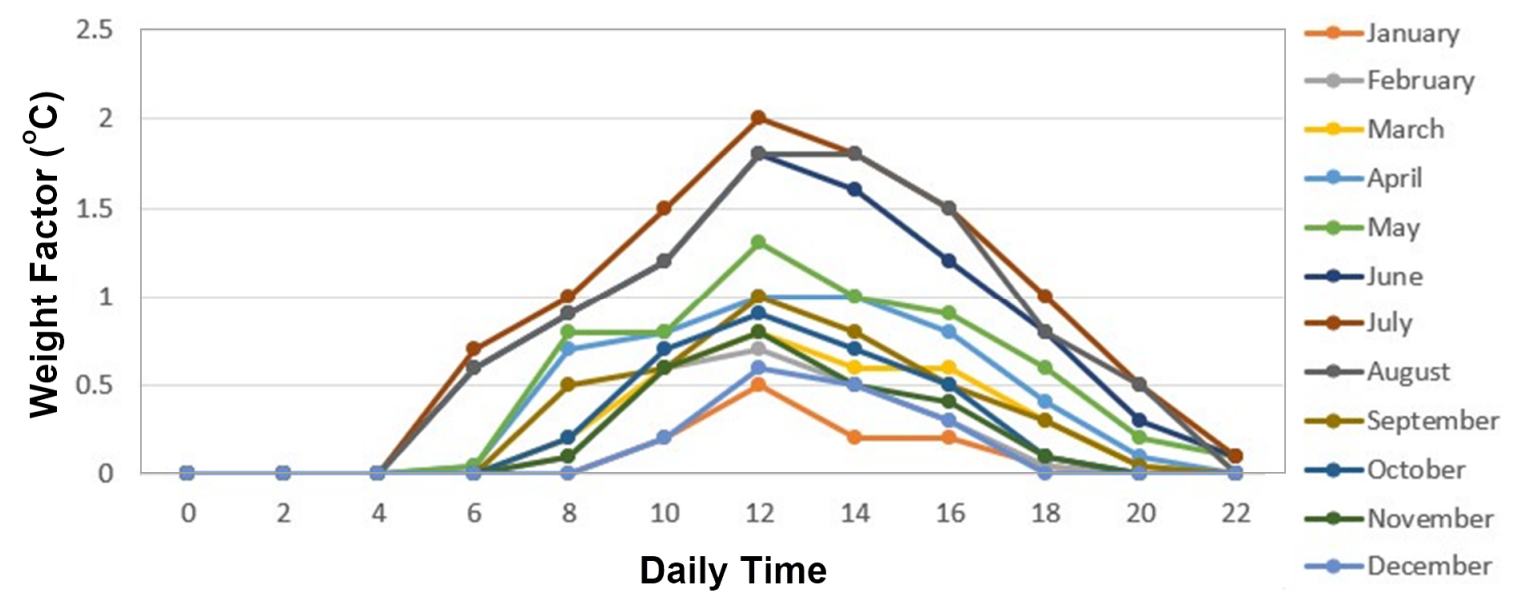

Figure 8. Monthly/hourly averaged weight factors of solar irradiation effects on the increased cooling demand of the buildings.

Figure 9 shows the rate of cold demand of one of the office buildings in the case study during 2018. According to the figure, the cooling demand could be up to about $300 \mathrm{~kW}$ during the hottest days of the year. The demand appears in the middle of April at a low rate and continues until early October, ending at a very low rate again.

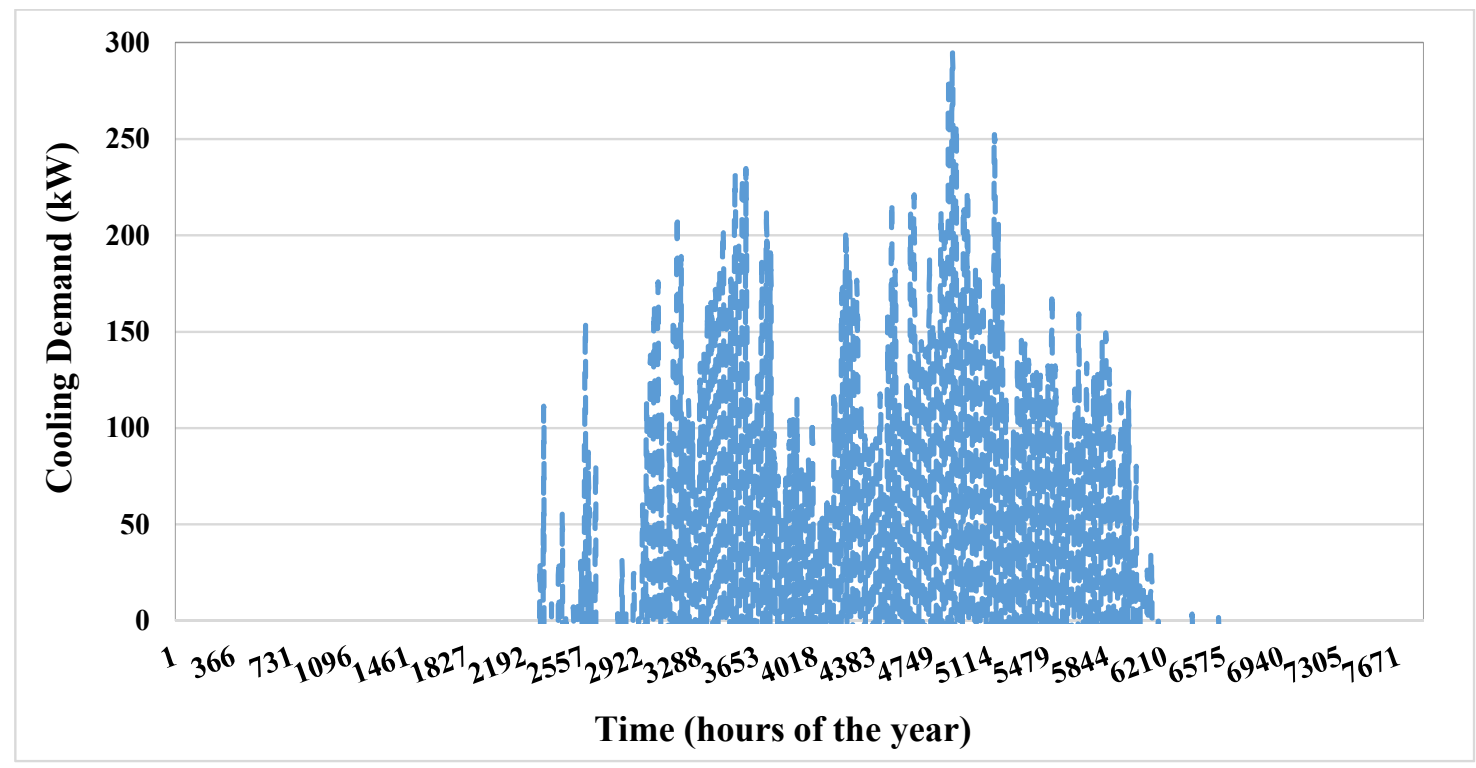

Figure 9. The rate of instantaneous cold demand of each of the buildings throughout the year.

Having 50 similar buildings, one finds out that the whole system capacity (including all the buildings and the rate of cold losses while transporting) should be about $14.8 \mathrm{MW}$. Thus, the absorption chiller is sized for this capacity. However, this method of sizing will result in oversizing the chiller with a high CAPEX, which is only working at high-load levels during a short period of the year. This sizing is accomplished based on the data of 2018. To prove the consequences of this method of sizing, Table 2 presents information about the details of the absorption chiller operation during 2017, 2018 and 2019. According to the table, the chiller will be operating at high loads during a very limited number of hours 
during the year. Thus, the sizing strategy should be changed. The alternative solution is providing the system with a cold storage unit in which surplus production of the chiller during the off-peak periods is stored for peak shaving. In this case, the absorption chiller capacity could be reduced to 6.7 MW, which is coupled with a storage tank with $8623 \mathrm{~m}^{3}$ (70.4 MWh) capacity. Note that for sizing the chiller, the largest total daily cooling demand of the year was calculated and the chiller was sized to the average hourly capacity of the chiller required for the given day.

Table 2. The absorption chiller operating statistics when sizing based on the maximum annual cold demand of the case study.

\begin{tabular}{cccc}
\hline Parameter & $\mathbf{2 0 1 7}$ & $\mathbf{2 0 1 8}$ & $\mathbf{2 0 1 9}$ \\
\hline Number of in-service hours & 1470 & 1494 & 1505 \\
\hline Average capacity ( $\%)$ & $23.2 \%$ & $32.9 \%$ & $26.4 \%$ \\
\hline Maximum used capacity ( $\%)$ & $61.0 \%$ & $100 \%$ & $94.4 \%$ \\
\hline Times with a higher operating capacity than $50 \%$ & $2.9 \%$ & $23 \%$ & $11 \%$ \\
\hline Times with a higher operating capacity than $70 \%$ & $0 \%$ & $5 \%$ & $4 \%$ \\
\hline
\end{tabular}

Having a storage tank for peak shaving could be significantly helpful for increasing the annual average cooling duty of the chiller and the number of operating hours at the nominal load, which is very important for getting better technical and economic outcomes. Figure 10 illustrates the operating load of the chiller during the year 2018 when coupled with the storage tank. As seen, the operating load of the system would increase significantly, and the chiller would be working at its full load capacity most of the time. Besides the economic benefits from the need for smaller capital investment for a smaller chiller, working at the nominal load levels is very important for energy systems because partial load operation strongly affects their performance and efficiency negatively.

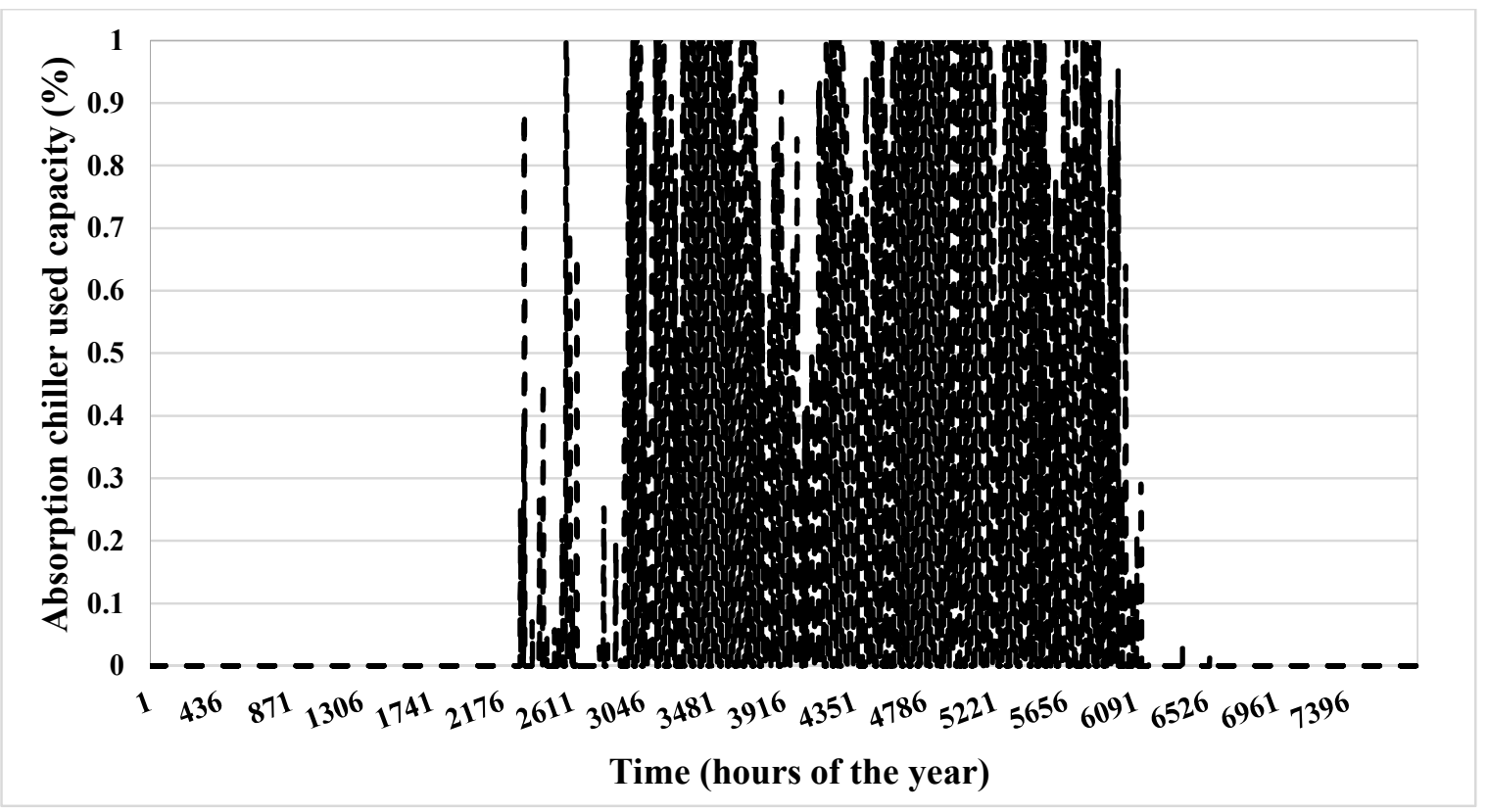

Figure 10. The operating rate of the chiller after adding a storage tank during 2018 (1 means 100\%).

Figure 11 presents information about the variation of the charging status of the storage tank during the year. As seen, the storage tank can simply be charged to $100 \%$ capacity at the beginning of the warm season when the cold demand is still low. Then, the storage tank will come into active interaction with the chiller for the cold supply of the office buildings. As seen, in the middle of the 
hot season the energy level of the storage drops to almost zero. This means that the storage tank has to be sized properly. This would prevent selecting a smaller storage unit leading to the district cooling system failing to reach a perfect supply of the network's demand, or a bigger one leading to unnecessary capital investment.

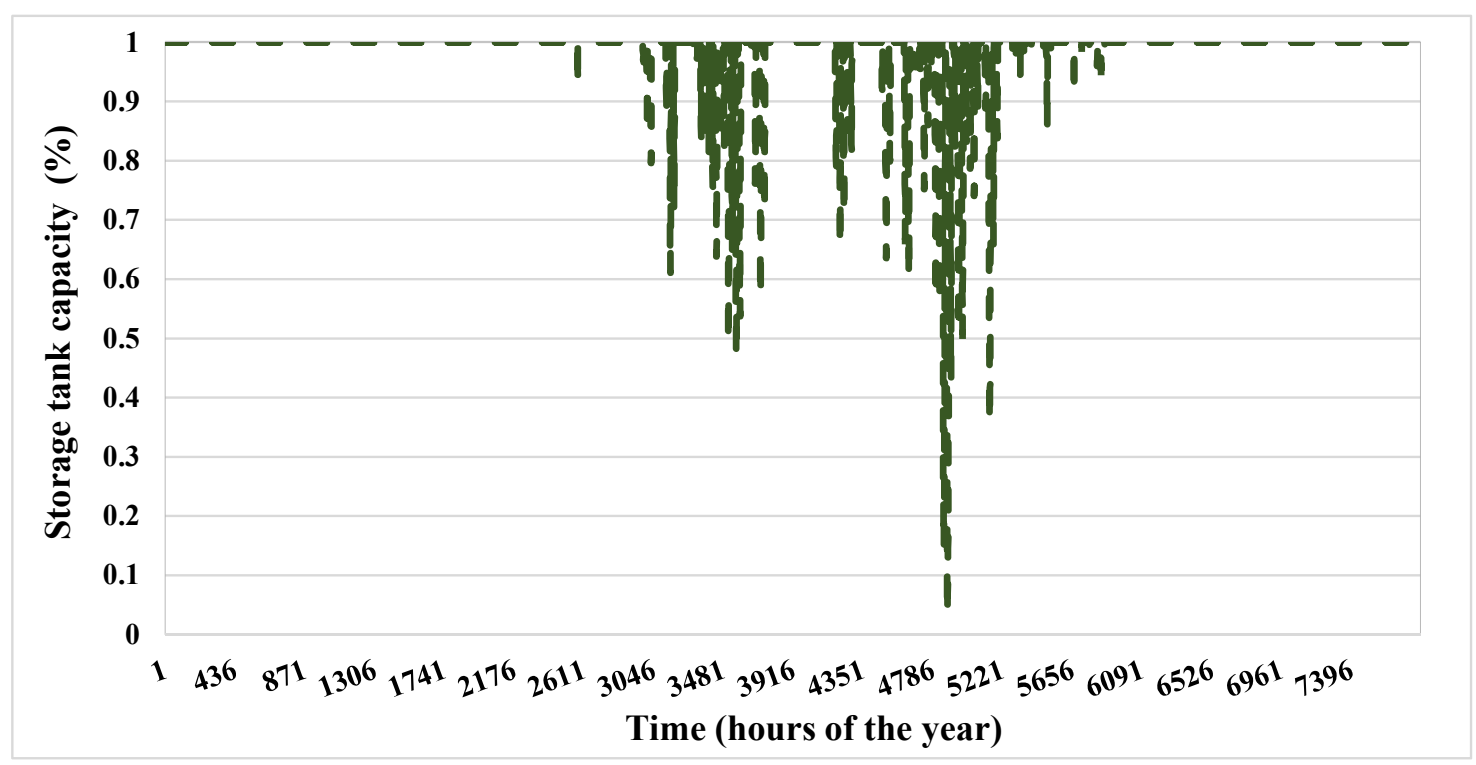

Figure 11. Charging level of the storage tank during the warm months of the year.

Table 3 presents the updated statistics of the data reported in Table 2 for the cooling system operating characteristics when using a cold storage tank and based on the new sizing strategy. According to the table, by using this method of sizing and adding the storage tank, not only could a big savings be achieved in the capital cost of the system, but there would also be a significant improvement in the utilization factor of the system capacity over the different years.

Table 3. The cooling system operating statistics when sized based on the new sizing strategy and adding a cold storage unit.

\begin{tabular}{ccccccc}
\hline \multirow{2}{*}{ Parameters } & \multicolumn{2}{c}{$\mathbf{2 0 1 7}$} & \multicolumn{2}{c}{$\mathbf{2 0 1 8}$} & \multicolumn{2}{c}{$\mathbf{2 0 1 9}$} \\
\cline { 2 - 7 } & Chiller & Storage Tank & Chiller & Storage Tank & Chiller & Storage Tank \\
\hline Number of in-service hours & 1470 & 146 & 1494 & 486 & 1505 & 388 \\
\hline Average capacity used (\%) & $53.5 \%$ & $95.8 \%$ & $66.2 \%$ & $83.7 \%$ & $56.0 \%$ & $83.3 \%$ \\
\hline Maximum used capacity (\%) & $100 \%$ & $18.7 \%$ & $100 \%$ & $96.6 \%$ & $100 \%$ & $80.6 \%$ \\
\hline $\begin{array}{c}\text { Times with a higher operating } \\
\text { capacity than 60\% }\end{array}$ & $43.4 \%$ & $0 \%$ & $59.7 \%$ & $4.7 \%$ & $46.4 \%$ & $5.1 \%$ \\
\hline
\end{tabular}

Table 4 presents information about the sizing of the pipeline of the case study district cooling system in different pipe sections, as well as the maximum mass flow rate and maximum pressure loss rate in each part of the pipeline.

Figure 12 presents the rates of electricity consumption in the system for the booster pumps allocated for pressure drop compensation and the pumps in the absorption cooler. Expectedly, the level of electricity consumption is not comparable with the level of cold supply as pumps consume so little power to operate. The peak electricity consumption in the system is about $340 \mathrm{~kW}$, which takes place somewhere in the middle of August. The average electricity consumption of the system during the cooling season is just about $60 \mathrm{~kW}$.

Figure 13 presents the rate of thermal energy losses from the pipeline during the year. Naturally, the data is only relevant as long as it is above zero, which means during the cooling 
seasons only. The negative values are for the months that the surrounding temperature of the pipes is below the district cooling medium in the supply and return pipes. Thus, during these times district heating systems are mainly operating at high-load levels. According to the figure, the rate of thermal losses from the system is also very low due to the very efficient pipes manufactured for district energy systems. The thermal losses will be up to $28 \mathrm{~kW}$ in the entire pipeline at the hottest time of the year. Previous experiences and observations of this study show that the rate of thermal losses are not greatly affected by the demand of the network, rather a function of the ambient temperature variations.

Table 4. The calculated dimensions of the pipeline of the district cooling system.

\begin{tabular}{ccccc}
\hline Pipeline Section & $\begin{array}{c}\text { Length } \\
(\mathbf{m})\end{array}$ & $\begin{array}{c}\text { Diameter } \\
(\mathbf{m})\end{array}$ & $\begin{array}{c}\text { Pressure Loss in } \\
\text { Supply/Return Lines (Pa/m) }\end{array}$ & $\begin{array}{c}\text { Max Mass Flow } \\
\text { Rate (kg/s) }\end{array}$ \\
\hline Transportation Line & 657 & 0.508 & $276 /-98$ & 502.1 \\
\hline Distribution-Section 1 & 300 & 0.406 & $75 / 73$ & 251.1 \\
\hline Distribution-Section 2 & 330 & 0.356 & $88 / 86$ & 190.8 \\
\hline Distribution-Section 3 & 330 & 0.324 & $69 / 67$ & 130.5 \\
\hline Distribution-Section 4 & 330 & 0.273 & $51 / 49$ & 70.3 \\
\hline Distribution-Section 5 & 50 & 0.114 & $111 / 108$ & 10 \\
\hline Total & $1997 \mathrm{~m}$ & & $373.3 \mathrm{kPa}$ & \\
\hline
\end{tabular}

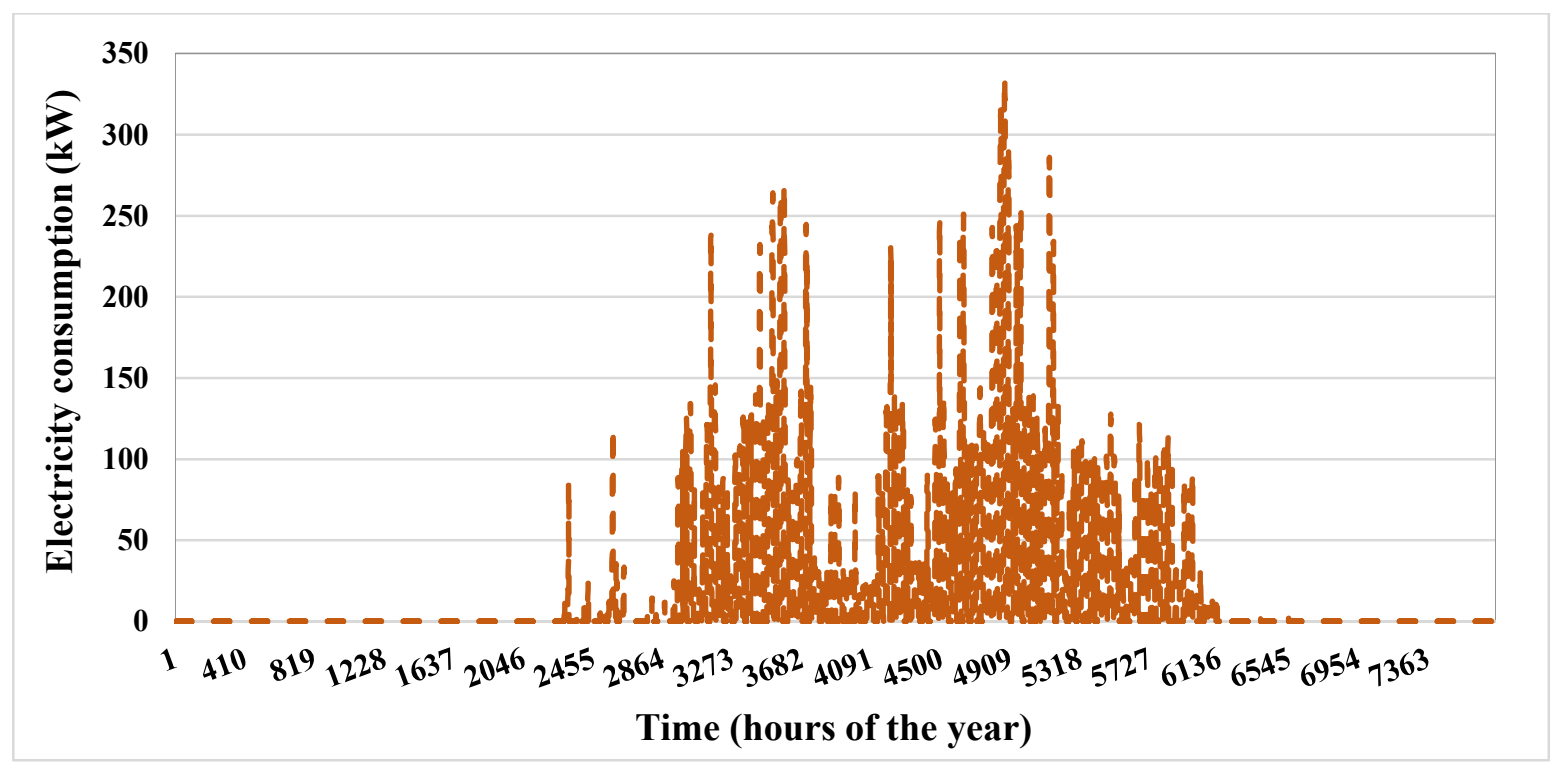

Figure 12. Rate of electricity consumption of the system over the year.

Table 5 summarizes the annual energy performance statistics of the system for an entire year of operation. As can be seen, although the total excess heat (due to 5026 tonnes of excess MSW) of the case study is about 17 GWh over the cooling season, the proposed district cooling system with 50 office buildings and over 20,000 working people takes advantage of only 10.4 GWh of that for cooling purposes. This is a strong indication of the high potential of such plants for the energy supply of large-scale district cooling networks. The proposed solution for such a small case study not only results in the efficient, purposive disposal of over 5000 tonnes of MSW but also leads to the supply of a total annual of about $7.3 \mathrm{GWh}$ of cooling to end-users, as well as approximately $2.9 \mathrm{GWh}$ of extra electricity production. All of these three parameters are actually direct economic benefits of the plant. 


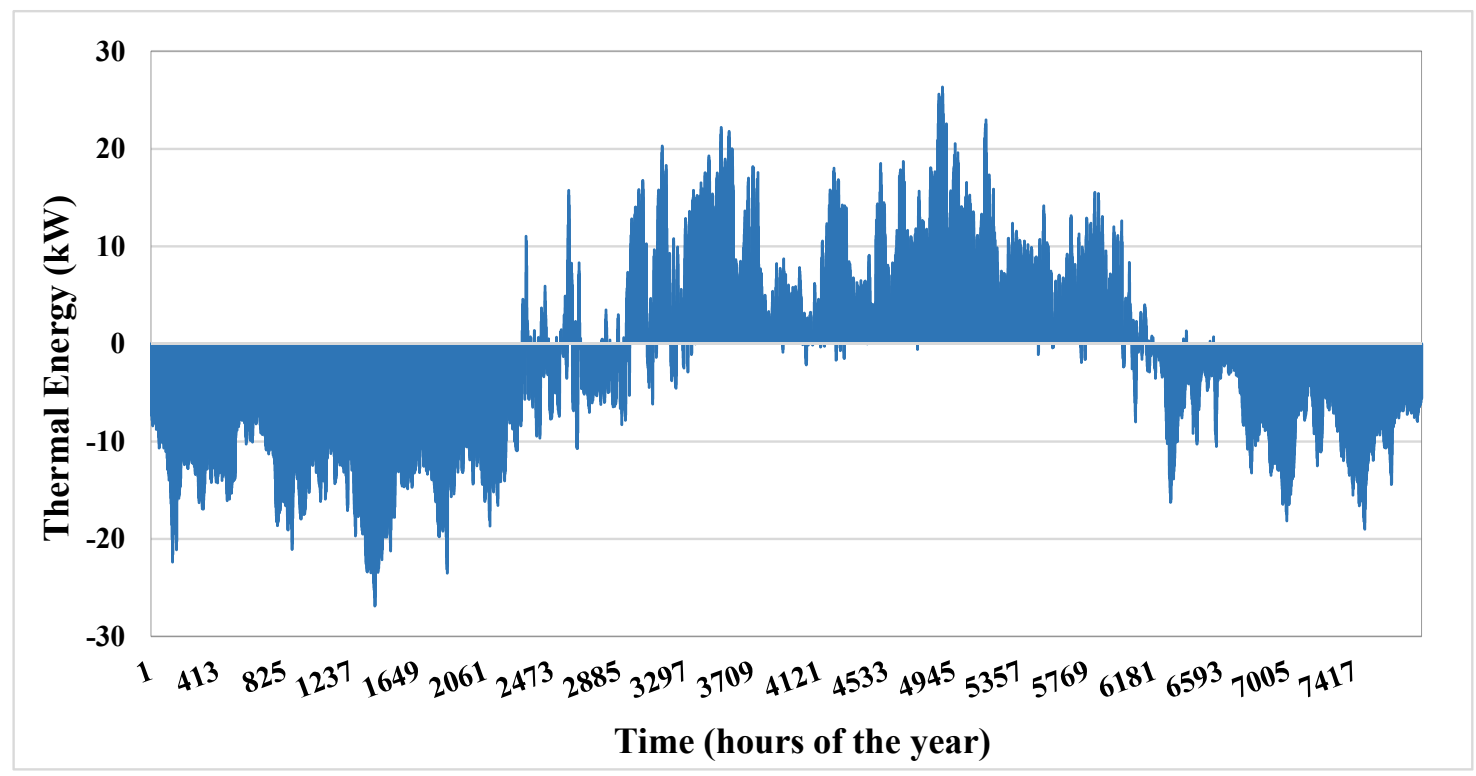

Figure 13. Rate of cold lost to the environment during the year.

Table 5. The total annual statistics of the system key parameters.

\begin{tabular}{cc}
\hline Parameter & Value and Unit \\
\hline Total excess heat of the CHP plant & $16,689 \mathrm{MWh}$ \\
\hline Total excess MSW of the CHP plant & 5026 tonne \\
\hline Total recovered heat by the chiller & $10,401 \mathrm{MWh}$ \\
\hline Total cooling supplied & $7281 \mathrm{MWh}$ \\
\hline $\begin{array}{c}\text { Total extra electricity production as a result of the } \\
\text { proposed system utilization }\end{array}$ & $2871 \mathrm{MWh}$ \\
\hline Total thermal losses & $67.7 \mathrm{MWh}$ \\
\hline Total electricity consumption & $107.4 \mathrm{MWh}$ \\
\hline
\end{tabular}

${ }^{*}$ Higher heating value $12500 \mathrm{MJ} / \mathrm{kg}$ [25].

Having the information presented by the above table, one could accomplish the economic analysis of the proposed solution in the waste-driven CHP plant. Figure 14 shows the trend of the variation of the NPV of the project over 25 years of the useful lifetime of the system for three cases. These three cases are for heat production taxation rates of 75 DKK/MWh, 150 DKK/MWh and 225 DKK/MWh as there is not a unique value for such taxations and also not a specific method for calculating that. According to the figure, the payback period of the proposed solution (when the NPV turns positive for the first time) is as short as five years, which is strongly impressive from an industrial investment point of view. In addition, the NPV of the system for this taxation fee case, at the end of the 25th operating year, is 4.7 million USD, which is almost 1.3 times larger than its initial investment, which is again strongly encouraging. For the taxation fees of $150 \mathrm{DKK} / \mathrm{MWh}$ and $225 \mathrm{DKK} / \mathrm{MWh}$, the payback periods will be a bit longer but still at very reasonable levels of 6.3 and 8.2 years.

Naturally, there are some uncertainties in the considered costs for the economic analyses of the project. Indeed, although the numbers come from authentic references, many unexpected parameters can affect the total cost or benefits of the system. Therefore, for accomplishing a sensitivity analysis on the economic outcomes of the proposed solution, Figure 15 shows the NPV of the project at the end of the 25th year of its operation (as its useful life span) for various CAPEX rates, OPEX rates (including excess heat production tax) and interest rates. The considered range for these rates is from $50 \%$ to $150 \%$ of the values considered in the NPV analysis of Figure 14 (i.e., those reported in 
Table 1). According to the table, the highest sensitivity of the economic outcomes is to the interest rate, where consideration of an interest rate half of that used for primary calculations $(10 \%$, half of which will be 5\%) will result in a huge NPV of $\$ 9.2$ million at the end of the system's lifetime. Clearly, a higher interest rate will result in lower NPV so that an interest rate of $15 \%$ would drop the NPV to $\$ 2.3$ million. It should be noted that the current inflation rate in Denmark is just about $0.5 \%$, and the interest rate of $10 \%$ is a very conservative rate usually taken for long-term investments with strict considerations in the industry. This clearly shows how the proposed solution is economically feasible. The variation of CAPEX of the system (including the cost of pipeline, chiller, the storage tanks, etc.) has the second most significant impact on the feasibility of the system among the considered parameters, though this impact is much milder than that of the interest rate effects. The changes in the OPEX costs (including the heat production taxes) have the least effect on the NPV value among all parameters.

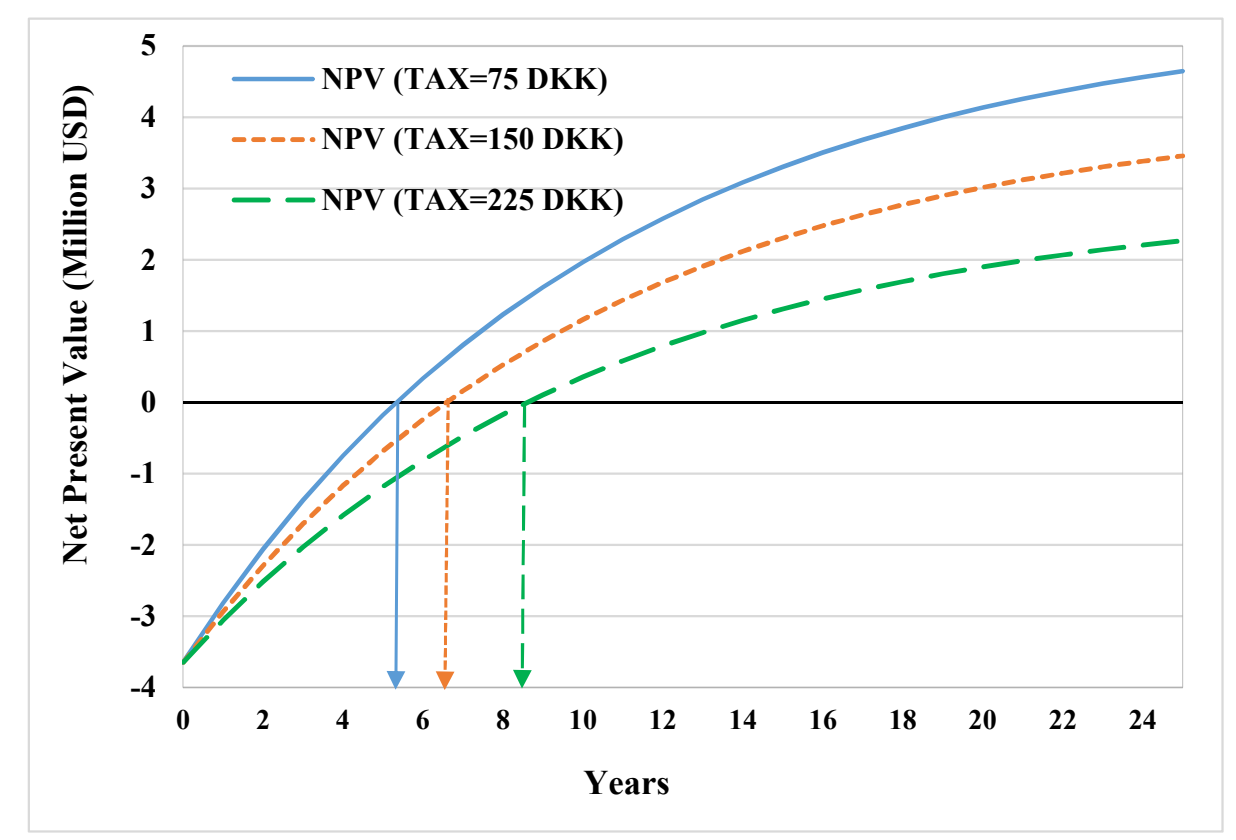

Figure 14. The NPV of the proposed solution over the useful lifetime.

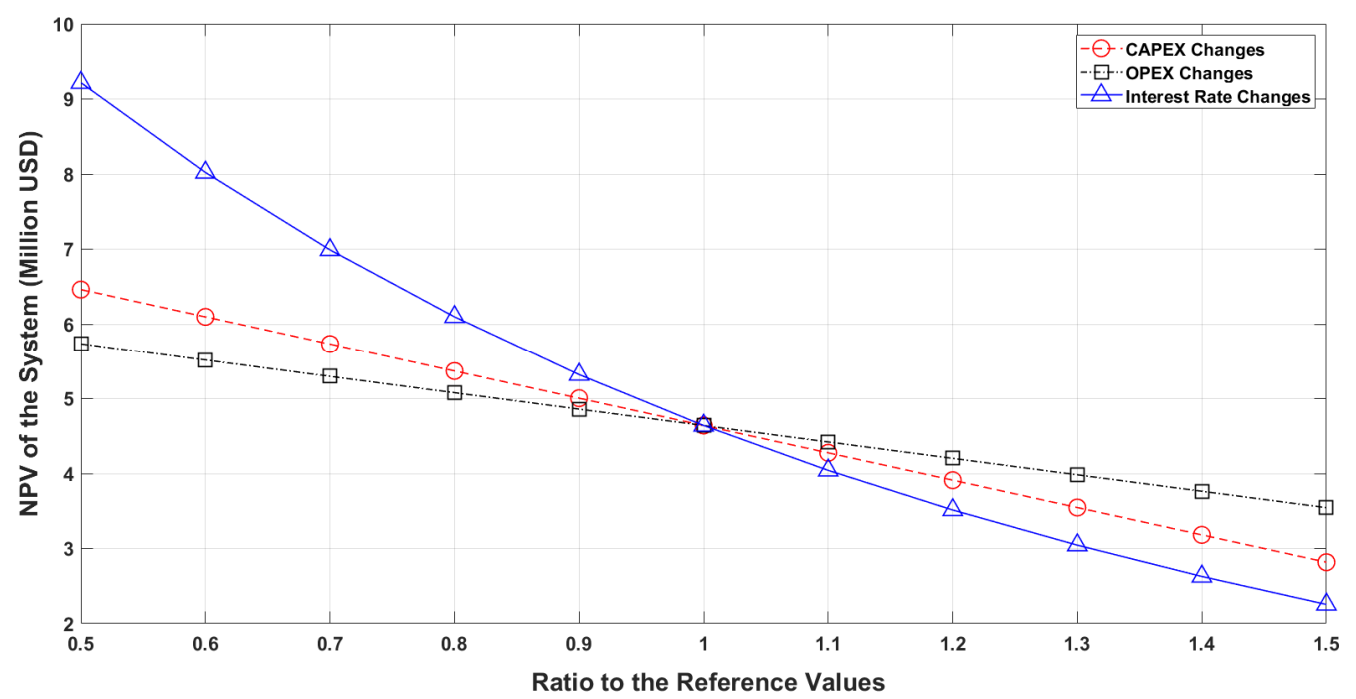

Figure 15. Sensitivity analysis of the economic proficiency of the proposed solution. 


\section{Conclusions}

In this study, an innovative yet effective solution was proposed for a techno-economic challenge of MSW-driven CHP plants that are connected to district heating systems. These plants are not exposed to enough heating loads and thus not only waste a massive amount of heating potential during the summer but also have the challenge of managing their excess MSW. Inspired by the increasing cold demand of the Northern European countries (where so many of such CHP plants are operating) over the last years due to climate change, this study proposed the utilization of the excess heat/MSW of such plants for driving a large-scale absorption machine to supply the energy demand of district cooling systems. To do the analysis based on real figures, an MSW CHP plant in Western Denmark and a number of office buildings in the neighborhood of the power plant were considered as the case study of this work. Considering the hourly averaged solar irradiation, ambient temperature, etc. of the case study area as well as real numbers of excess heat and excess MSW during the year, the proposed solution was modeled for three consecutive years. The modeling was aimed at presenting the details of the thermodynamic performance of the system and how things could be synchronized for the ultimate goal of the project, and also to do an economic analysis of the proposed solution to check its feasibility for real-life implementation.

It was shown that a combination of an absorption chiller with a large cold storage tank is the best arrangement for the system techno-economically. This combined energy supply system integrated with the district cooling pipeline can prevent approximately $10.4 \mathrm{GWh}$ of thermal energy of the CHP plant being wasted, 5000 tonnes of MSW being effectively incinerated (which was a serious challenge to manage in the conventional system) and $7300 \mathrm{MWh}$ of cooling being supplied to the end-users. This solution not only solves the challenge of the techno-economic power plant and makes a substantial economic profit, but also solves the cooling problem of the office buildings which has been a seriously unmet need over the last years. The economic analysis shows that the payback period of the system is as short as five years. The NPV of the system at the end of the 25th year of operation of the system was found to be 4.7 million USD. This short period of retuning the initial investment and the considerable NPV of the system at the end of its useful lifetime (based on a conservative number) can be, indeed, a strong incentive for implementing this solution in any waste-driven CHP plant with the same techno-economic challenge during the warm months of the year.

Author Contributions: Conceptualization, A.A., T.W.R.; methodology: A.A., M.F., D.Ø.T., T.W.R.; software, M.F., D.Ø.T., T.W.R.; investigation, M.F., D.Ø.T., T.W.R.; writing—original draft preparation, M.F., D.Ø.T., T.W.R.; writing-review and editing, A.A.; supervision, A.A. All authors have read and agreed to the published version of the manuscript.

Funding: This research received no external funding.

Conflicts of Interest: The authors declare no conflict of interest.

\section{References}

1. Eurostat. 2012. Available online: https://ec.europa.eu/eurostat/web/lucas/data/primary-data/2012 (accessed on 1 October 2019).

2. Yang, W.; Nam, H.-S.; Choi, S. Improvement of operating conditions in waste incinerators using engineering tools. Waste Manag. 2007, 27, 604-613. [CrossRef] [PubMed]

3. Ghouleh, Z.; Shao, Y. Turning municipal solid waste incineration into a cleaner cement production. J. Clean. Prod. 2018, 195, 268-279. [CrossRef]

4. European Commission. The Role of Waste-to-Energy in the Circular Economy, Communication from the Commission to the European, Parliament, the Council, the European Economic and Social, Committee and The Committee of the Regions (2017) 11. Available online: http://ec.europa.eu/environment/waste/waste-toenergy.pdf (accessed on 1 October 2019).

5. Sadi, M.; Arabkoohsar, A. Exergoeconomic analysis of a combined solar-waste driven power plant. Renew. Energy 2019, 141, 883-893. [CrossRef] 
6. Arabkoohsar, A.; Sadi, M. Thermodynamics, economic and environmental analyses of a hybrid waste-solar thermal power plant. J. Therm. Anal. Calorim. 2020, 1-24. [CrossRef]

7. Sadi, M.; Arabkoohsar, A. Modelling and analysis of a hybrid solar concentrating-waste incineration power plant. J. Clean. Prod. 2019, 216, 570-584. [CrossRef]

8. Bourtsalas, A.C.; Seo, Y.; Alam, T.; Seo, Y.-C. The status of waste management and waste to energy for district heating in South Korea. Waste Manag. 2019, 85, 304-316. [CrossRef] [PubMed]

9. Rudra, S.; Tesfagaber, Y.K. Future district heating plant integrated with municipal solid waste (MSW) gasification for hydrogen production. Energy 2019, 180, 881-892. [CrossRef]

10. Münster, M.; Meibom, P. Optimization of use of waste in the future energy system. Energy 2011, 36, 1612-1622. [CrossRef]

11. Furtenback, Ö. Demand for waste as fuel in the swedish district heating sector: A production function approach. Waste Manag. 2009, 29, 285-292. [CrossRef]

12. Nami, H.; Arabkoohsar, A. Improving the Power Share of Waste-Driven CHP Plants via Parallelization with a Small-Scale Rankine Cycle, a Thermodynamic Analysis. Energy 2019, 171, 27-36. [CrossRef]

13. Arabkoohsar, A.; Nami, H. Thermodynamic and economic analyses of a hybrid waste-driven CHP-ORC plant with exhaust heat recovery. Energy Convers. Manag. 2019, 187, 512-522. [CrossRef]

14. Gang, W.; Wang, S.; Xiao, F.; Gao, D.-C. District cooling systems: Technology integration, system optimization, challenges and opportunities for applications. Renew. Sustain. Energy Rev. 2016, 53, 253-264. [CrossRef]

15. Werner, S. International review of district heating and cooling. Energy 2017, 137, 617-631. [CrossRef]

16. Inayat, A.; Raza, M. District cooling system via renewable energy sources: A review. Renew. Sustain. Energy Rev. 2019, 107, 360-373. [CrossRef]

17. Eveloy, V.; Ayoua, D.S. Sustainable district cooling systems: Status, challenges, and future opportunities, with emphasis on cooling-dominated regions. Energies 2019, 12, 235. [CrossRef]

18. Arabkoohsar, A.; Andersen, G.B. Design and optimization of a novel system for trigeneration. Energy 2019, 168, 247-260. [CrossRef]

19. Nami, H.; Anvari-Moghaddam, A.; Arabkoohsar, A. Application of CCHPs in a Centralized Domestic Heating, Cooling and Power Network - Thermodynamic and Economic Implications. Sustain. Cities Soc. 2020, 102151. [CrossRef]

20. Wang, Z.; Li, H.; Zhang, X.; Wang, L.; Du, S.; Fang, C. Performance analysis on a novel micro-scale combined cooling, heating and power (CCHP) system for domestic utilization driven by biomass energy. Renew. Energy 2020, 156, 1215-1232. [CrossRef]

21. Soltani, M.; Chahartaghi, M.; Hashemian, S.M.; Shojaei, A.F. Technical and economic evaluations of combined cooling, heating and power (CCHP) system with gas engine in commercial cold storages. Energy Convers. Manag. 2020, 214, 112877. [CrossRef]

22. Zare, V.; Takleh, H.R. Novel geothermal driven CCHP systems integrating ejector transcritical $\mathrm{CO}_{2}$ and Rankine cycles: Thermodynamic modeling and parametric study. Energy Convers. Manag. 2020, 205, 112396. [CrossRef]

23. Wu, D.; Zuo, J.; Liu, Z.; Han, Z.; Zhang, Y.; Wang, Q.; Li, P. Thermodynamic analyses and optimization of a novel CCHP system integrated organic Rankine cycle and solar thermal utilization. Energy Convers. Manag. 2019, 196, 453-466. [CrossRef]

24. Hedberg, E.; Project, D. Potential for Absorption Cooling Generated from Municipal Solid Waste in Bangkok; Linköpings University: Linköping, Swden, 2010.

25. Nami, H.; Arabkoohsar, A.; Anvari-Moghaddam, A. Thermodynamic and sustainability analysis of a municipal waste-driven combined cooling, heating and power (CCHP) plant. Energy Convers. Manag. 2019, 201, 112158. [CrossRef]

26. Florides, G.; Kalogirou, S.; Tassou, S.A.; Wrobel, L.C. Design and construction of a LiBr-water absorption machine. Energy Convers. Manag. 2003, 44, 2483-2508. [CrossRef]

27. Energnist.dk. Energnist Esbjerg. 2018. Available online: http://www.energnist.dk/ (accessed on 1 October 2019).

28. Esbjerg Kommune. Fakta om Kommunen. Available online: https://www.esbjerg.dk/ (accessed on 1 October 2019).

29. Bygningsreglementet. Energiforbrug, Generelle Mindstekrav til Klimaskærm., (n.d.). 2018. Available online: http:\%0A//bygningsreglementet.dk/Tekniske-bestemmelser/11/Krav (accessed on 1 October 2019). 
30. Arbejstilsynet. Temperatur i Arbejdsrum på Faste Arbejdssteder., (n.d.). 2005. Available online: https: //amid.dk/\%0Aregler/at-vejledninger/temperatur-arbejdsrum-faste-arbejdsstedera-\%0A1-12/ (accessed on 1 October 2019).

31. Semmari, H.; Filali, A.; Aberkane, S.; Feidt, R.; Feidt, M. Flare gas waste heat recovery: Assessment of organic rankine cycle for electricity production and possible coupling with absorption chiller. Energies 2020, $13,2265$. [CrossRef]

32. Arabkoohsar, A. Non-uniform temperature district heating system with decentralized heat pumps and standalone storage tanks. Energy 2019, 170, 931-941. [CrossRef]

33. "Standard 55-2017". Thermal Environmental Conditions for Human Occupancy. Available online: https://www.ashrae.org/technical-resources/bookstore/standard-55-thermal-environmental-conditionsfor-human-occupancy (accessed on 1 October 2019).

34. Yu, Y.-H.; Lin, C.-Y.; Yang, C.-H. Human body surface area database and estimation formula. Burns 2010, 36, 616-629. [CrossRef]

35. Moallemi, A.; Arabkoohsar, A.; Pujatti, F.; Valle, R.; Ismail, K. Non-uniform temperature district heating system with decentralized heat storage units, a reliable solution for heat supply. Energy 2019, 167, 80-91. [CrossRef]

36. District Heating Supplier of South Denmark, (n.d.). Available online: https://dinforsyning.dk/ (accessed on 1 October 2019).

37. Incropera, F.P.; Bergman, T.L.; Lavine, A.S.; DeWitt, D.P. Fundamentals of Heat and Mass Transfer; John Wiley \& Sons, Inc.: Hoboken, NJ, USA, 2011. [CrossRef]

38. For Dataforsyning og Effektivisering, S., 2019. Dhm-2007/højdekurver., (n.d.). Available online: https: //download.kortforsyningen.dk/content/dhm-\%0A2007h\T1\ojdekurver (accessed on 1 October 2019).

39. Stark, J.P. Fundamentals of classical thermodynamics (Van Wylen, Gordon J.; Sonntag, Richard E.). J. Chem. Educ. 1966, 43, A472. [CrossRef]

40. Arabkoohsar, A.; Alsagri, A.S. A new generation of district heating system with neighborhood-scale heat pumps and advanced pipes, a solution for future renewable-based energy systems. Energy 2020, 193, 116781. [CrossRef]

41. Calise, F.; Cappiello, F.L.; Dentice, M.; Vicidomini, M. Thermo-Economic Analysis of Hybrid Solar-Geothermal Polygeneration Plants in Di ff erent Configurations. Energies 2020, 13, 2391. [CrossRef]

42. Shafiee, M.; Alghamdi, A.; Sansom, C.; Hart, P.; Encinas-Oropesa, A. A through-life cost analysis model to support investment decision-making in concentrated solar power projects. Energies 2020, 13, 1553. [CrossRef]

43. Bhatia, A. Overview of Vapor Absorption Cooling Systems Course No: M04-025 Credit: 4 PDH. Available online: https://www.cedengineering.com/courses/overview-of-vapor-absorption-cooling-systems (accessed on 1 October 2019).

44. Ramboll Energy. Available online: www.Ramboll.dk (accessed on 1 October 2019).

45. Logstor, DH Pipeline Developer. Available online: www.Logstor.dk (accessed on 1 October 2019).

(C) 2020 by the authors. Licensee MDPI, Basel, Switzerland. This article is an open access article distributed under the terms and conditions of the Creative Commons Attribution (CC BY) license (http://creativecommons.org/licenses/by/4.0/). 